\title{
DDR2 Expression Is Associated with a High Frequency of Peritoneal Dissemination and Poor Prognosis in Colorectal Cancer
}

\author{
SHIN SASAKI ${ }^{*}$, MASAMI UEDA $^{2 *}$, TOMOHIRO IGUCHI ${ }^{2}$, MANABU KANEKO $^{1}$, \\ HIROSHI NAKAYAMA ${ }^{1}$, TOSHIYUKI WATANABE ${ }^{1}$, ATSUHIKO SAKAMOTO ${ }^{3}$ and KOSHI MIMORI ${ }^{2}$ \\ ${ }^{1}$ Department of Surgery, Omori Red Cross Hospital, Tokyo, Japan; \\ ${ }^{2}$ Department of Surgery, Kyushu University Beppu Hospital, Beppu, Japan; \\ ${ }^{3}$ Department of Pathology and Laboratory Medicine, Omori Red Cross Hospital, Tokyo, Japan
}

\begin{abstract}
Background: We previously identified discoidindomain receptor 2 (DDR2) as a promising driver gene of peritoneal dissemination (PD) in gastric cancer. In the present study we explored the clinical significance of DDR2 expression in colorectal cancer (CRC). Materials and Methods: We examined DDR2 expression in CRC specimens by immunohistochemistry. We analyzed the association of DDR2 expression with clinicopathological factors in CRC. We divided 63 CRC cases into two groups according to their level of DDR2 expression and compared several clinicopathological factors and their overall survival. Results: The group with high DDR2 expression had significantly higher frequencies of T4, lymph node metastasis, and PD compared to the group with low DDR2 expression. Furthermore, the prognosis of the group with high DDR2 expression was significantly poorer than the group with low DDR2. Conclusion: DDR2 is a powerful biomarker that can predict poor prognosis as well as $P D$, and might be an effective therapeutic target for CRC.
\end{abstract}

Colorectal cancer (CRC) is one of the most commonly diagnosed cancers worldwide. After the liver, peritoneal dissemination (PD) is the second-most frequent site for CRC metastasis. Peritoneal dissemination is estimated to occur in $4-7 \%$ of CRC patients at the time of diagnosis, and in

\footnotetext{
*These Authors contributed equally to this study.

Correspondence to: Prof. Koshi Mimori, MD, Ph.D., Department of Surgery, Kyushu University, Beppu Hospital, 4546 Tsurumihara, Beppu, Oita, 874-0838, Japan. Tel: +81 977271650, Fax: +81 977271651, e-mail: kmimori@beppu.kyushu-u.ac.jp
}

Key Words: Discoidin domain receptor 2 (DDR2), peritoneal dissemination, colorectal cancer. approximately $4-19 \%$ of patients during follow-up after curative surgery (1-4).

The prognosis of patients with PD is poor: median survival is 6-9 months after diagnosis. PD has, therefore, been considered a terminal state and only palliative therapy is generally performed. Recently, advanced CRC has been treated with chemotherapy combined with effective cytotoxic anticancer agents and molecular-targeted drugs; however, there has been no significant improvement of survival for CRC dissemination (5-7). Cytoreductive surgery combined with hyperthermic intraperitoneal chemotherapy has also been recently introduced as a treatment for PD, but this therapy is effective only in a limited population of patients $(8,9)$.

To improve the treatment outcome for CRC patients with $\mathrm{PD}$, a powerful biomarker for identifying and predicting PD occurrence is required. We recently used gene expression analysis to show that a type I collagen receptor tyrosine kinase called discoidin-domain receptor 2 (DDR2) is a driver of peritoneal dissemination of gastric cancer and could be used as a novel therapeutic target (10).

Herein, we clarified how DDR2 expression is associated with PD and determine whether DDR2 could be used as a biomarker for identifying PD and a poor prognosis in CRC. We analyzed DDR2 expression in primary CRC tissue, as well as in PD lesions with immunohistochemical staining, and identified associations between the DDR2 expression and several clinicopathological factors including overall survival.

\section{Materials and Methods}

Subjects. This study included 63 patients with primary CRC who underwent surgical treatment at the Department of Surgery, Omori Red Cross Hospital, between January 2009 and December 2014. Among them, 13 patients had synchronous PD, though only 10 PD lesions were available for our use. All subjects were informed about the study and gave written consent for investigation in accordance 
with the ethical guidelines of our hospital. For all 63 primary CRC samples and 10 available PD lesions, 5-micron sections were prepared from formalin-fixed, paraffin-embedded tissue and mounted onto slides coated with polylysin. Clinical and pathological documents from each case were used to obtain data including age, gender, histological type, size, tumor location, TNM stage, T category, lymph node metastasis, lymphatic and venous invasion, $\mathrm{P}$ and $\mathrm{H}$ factors, and overall survival.

Immunohistochemistry. Tissue sections were deparaffinized and boiled in $0.01 \mathrm{~mol} / \mathrm{l}$ sodium citrate buffer in a microwave for $10 \mathrm{~min}$ at $500 \mathrm{~W}$ for antigen retrieval. Rabbit polyclonal DDR2 antibodies (H-108, Santa Cruz Biotechnology, Santa Cruz, CA) diluted to 1:100 were used as the primary antibody. All tissue sections were immunohistochemically stained with ENVISION reagents (ENVISION1 Dual Link/HRP, Dako, Glostrup, Denmark) and counterstained with hematoxylin.

Evaluation and statistical analysis. Two different investigators who had no knowledge of the associated clinicopathological features evaluated the immunostained specimens. We assigned blood cells as a positive control, and classified their DDR2 staining level as 3+. Each lesion was split up into fields, and the average intensity of DDR2 staining was calculated. For three different areas of the lesion, the proportion of fields exhibiting $3+$ staining was calculated, and used to classify the 63 cases into two groups of high average intensity of DDR2 expression (high-DDR2) and low average intensity (low-DDR2). Data were analyzed using the software JMP 5 (JMP, Cary, NC, USA). Statistical analyses were performed using a likelihood chi-squared analysis, a Fisher's exact test, or a Mann-Whitney $U$-test. The overall survival curves were plotted according to the Kaplan-Meier method, and a generalized Log-rank test was applied to compare the survival curves. The findings were considered significant at a $p$-value $<0.05$.

\section{Results}

Using immunohistochemistry, we found that DDR2 expression is non-existent or very weak in normal colorectal tissue, but in CRC lesions DDR2 expression is generally higher in the invasive front than in other areas. In each case, we randomly chose three different invasive fronts from the lesion and calculated the proportion of the fields exhibiting 3+ staining (Figure 1a-c). In all cases, the average proportion of fields positive for DDR2 expression was $48.8 \%$. We categorized the twenty cases whose intensity of DDR2 expression was above this average as the high-DDR2 group and the forty-three cases with below-average staining intensity as the low-DDR2 group (Figure 2). Nine out of 10 PD lesions exhibited positive staining for DDR2 expression (Figure 1d).

The relationship between DDR2 expression and clinicopathological factors is summarized in Table I. DDR2 expression was not significantly associated with age, gender, histological type, size, tumor location, TNM stage, lymphatic and venous invasion, or $\mathrm{H}$ factors. However, the proportion of T4 in the high-DDR2 group was significantly higher than in the low-DDR2 group $(p=0.0025)$. Lymph node metastasis
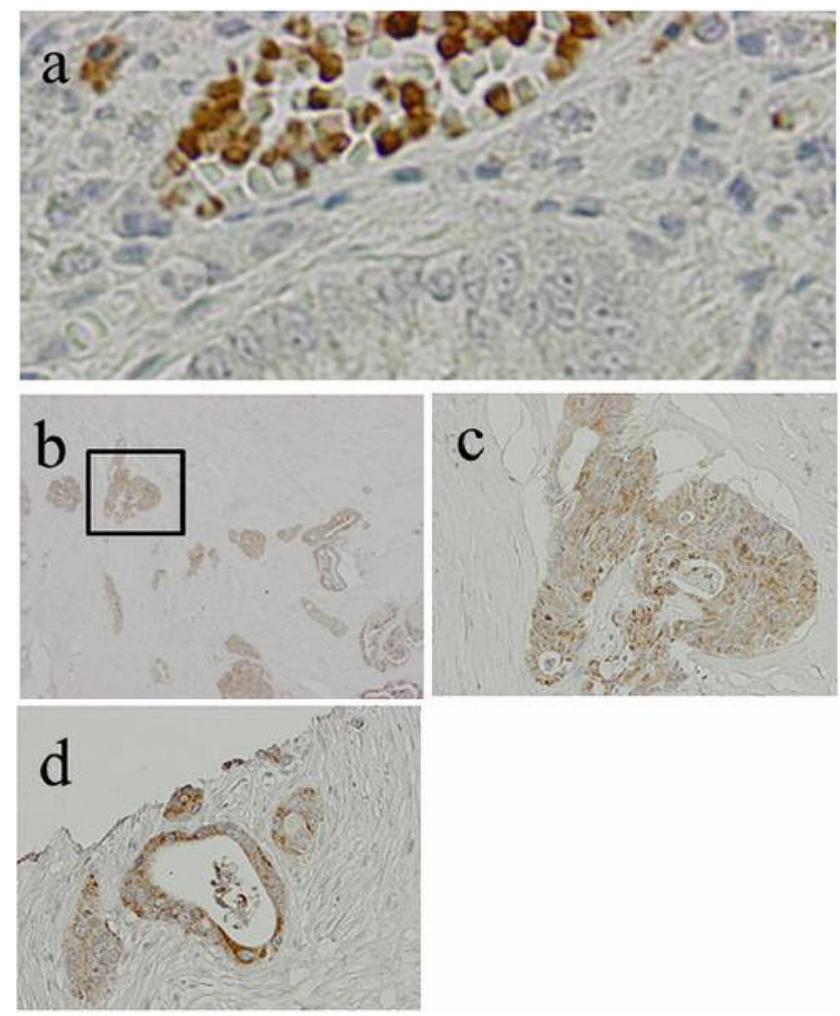

Figure 1. DDR2 expression by immunohistochemical analysis. (a) Blood cells were used as a positive control, and the intensity of their DDR2 staining was classified as $3+.(b, c)$ Representative staining of DDR2 expression in primary colorectal cancer. $b$ and $c$ show DDR2 expression in the same lesion at low and high power magnification, respectively. (d) Representative staining of DDR2 expression in lesions of peritoneal dissemination.

was also detected more frequently in the high-DDR2 group than in the low-DDR2 group $(p=0.012)$. Furthermore, PD occurred more frequently in the high-DDR2 group than in the low-DDR2 group $(p=0.012)$. The overall survival for patients in the high-DDR2 group was also significantly worse than in the low-DDR2 group $(p=0.0164)$ (Figure 3).

\section{Discussion}

In the current study, we demonstrated that DDR2 is expressed to a larger amount in CRC cells than normal duct cells. DDR2 is overexpressed not only in the invasive front of primary CRC tissue, but also in PD tissues. We showed that the high-DDR2 patient group had a significantly higher proportion of T4, lymph node metastasis, and PD than the low-DDR2 group. Furthermore, we found that the overall survival of patients in the high-DDR2 group was significantly poorer than that in the low-DDR2 group. These results show clearly that DDR2 expression in CRC is 


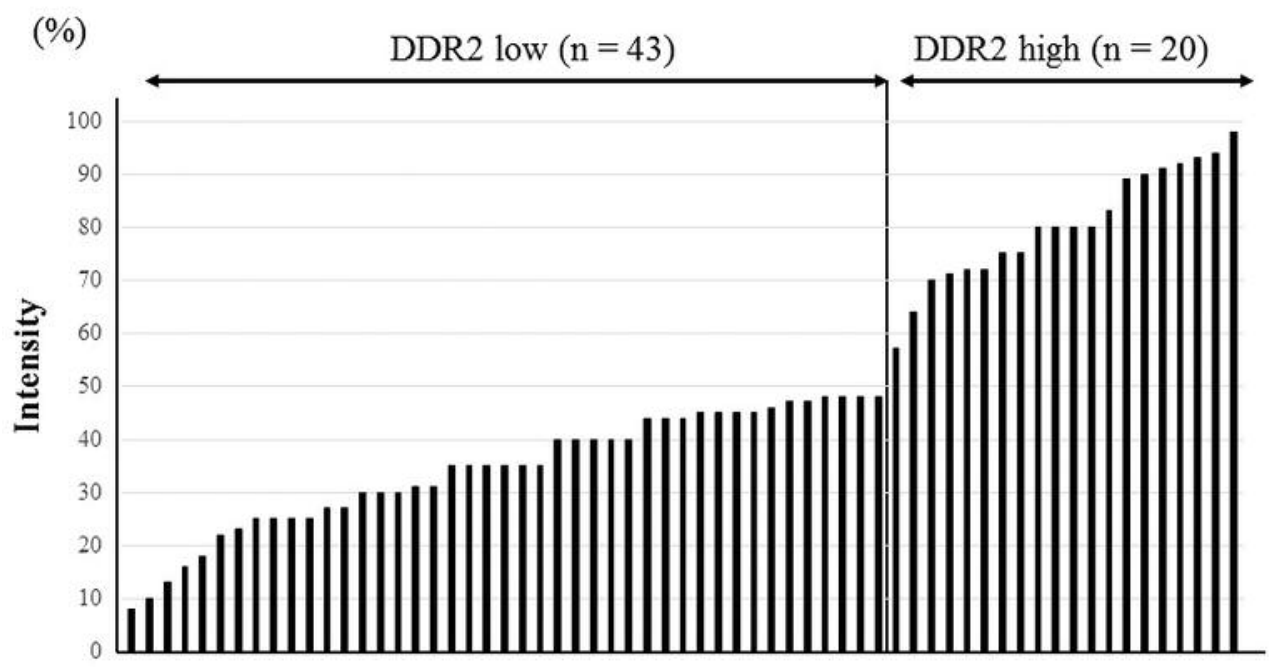

the mean intensity: $48.8(\%)$

CRC patients $(\mathrm{n}=63)$

Figure 2. Intensity of DDR2 expression in 63 primary colorectal cancer patients. Forty-three patients were categorized into the low-DDR2 expression group and twenty patients into the high-DDR2 expression group. High or low expression intensity was determined by whether the case fell above or below the average intensity of DDR2 expression (48.8\%).

associated with PD and poor prognosis. We suggest that DDR2 expression might be a useful prognostic marker in the clinical setting, especially for PD. Moreover, earlier studies have demonstrated that DDR2 modulates the migration and invasiveness of various cancer cells, and overexpression of NOV is related to poor prognosis in lung cancer, urothelial carcinoma and ovarian cancer, higher rates of metastasis in breast cancer, which supports our results (11-19).

PD is one route of distant metastasis in gastrointestinal carcinomas, and is an obviously life threatening state. After the liver, PD is the second-most frequent site for CRC metastasis. It is a factor for poor prognosis in CRC. A multistep process is necessary to establish PD. First, cancer cells scatter into the abdominal cavity from the primary carcinoma and then adhere to the peritoneum. Finally, the cells must invade the submesothelial layers. The molecular mechanisms driving PD have, therefore, been assumed to involve the expression of genes related to the extracellular matrix (ECM), focal cell-cell adhesion, and apoptosis. DDR2 is a type I collagen receptor tyrosine kinase that interacts with Src following transactivation of the matrix metalloproteinase2 promotor (20). It was previously demonstrated to be the driver gene of PD in gastric cancer (10).

Src belongs to a family of non-receptor cytoplasmic protein tyrosine kinases that function in signaling complexes. They recruit and participate in intracellular signal transduction pathways thought to be associated with carcinogenesis as well as angiogenesis, migration, invasion, adhesion, and cell

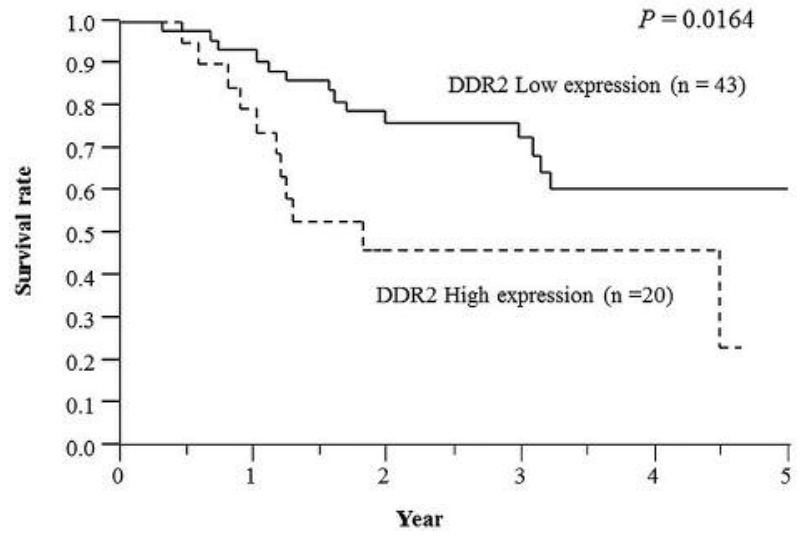

Figure 3. DDR2 expression is associated with a poor prognosis in colorectal cancer. The Kaplan-Meier survival curves of the 63 cases enrolled in this study according to their DDR2 expression classification.

proliferation and differentiation (21-23). In CRC, both Src kinase activity and protein expression levels are elevated compared to normal colonic mucosal cells (24-26). Src expression and activity is also remarkably increased in CRC liver metastases $(27,28)$, and elevated Src levels correlate with a worse survival rate (29). Furthermore, it has been shown that the Src inhibitor dasatinib is effective in enhancing the sensitivity of CRC cells to chemotherapy. Our report suggests that DDR2 expression in CRC might be an effective 
Table I. Relationships between DDR2 expression and clinicopathological factors.

\begin{tabular}{|c|c|c|c|}
\hline \multirow[t]{2}{*}{ Factors } & \multicolumn{2}{|c|}{ DDR2 expression } & \multirow[t]{2}{*}{$p$-Value } \\
\hline & $\begin{array}{c}\text { High } \\
\text { expression } \\
n=20\end{array}$ & $\begin{array}{c}\text { Low } \\
\text { expression } \\
n=43\end{array}$ & \\
\hline \multicolumn{4}{|l|}{ Age } \\
\hline$\leq 65$ & 3 & 12 & \multirow[t]{2}{*}{0.24} \\
\hline$>65$ & 17 & 31 & \\
\hline \multicolumn{4}{|l|}{ Gender } \\
\hline Male & 12 & 27 & \multirow[t]{2}{*}{0.83} \\
\hline Female & 8 & 16 & \\
\hline \multicolumn{4}{|l|}{ Histology } \\
\hline tub1 & 3 & 8 & \multirow[t]{2}{*}{0.72} \\
\hline Others & 17 & 35 & \\
\hline \multicolumn{4}{|l|}{ Size } \\
\hline$<5 \mathrm{~cm}$ & 7 & 16 & \multirow[t]{2}{*}{0.86} \\
\hline $5 \mathrm{~cm} \leq$ & 13 & 27 & \\
\hline \multicolumn{4}{|l|}{ Tumor location } \\
\hline Right colon & 6 & 17 & \multirow[t]{3}{*}{0.22} \\
\hline Left colon & 9 & 10 & \\
\hline Rectum & 5 & 16 & \\
\hline \multicolumn{4}{|l|}{ TNM stage } \\
\hline $\mathrm{I} / \mathrm{II}$ & 2 & 11 & \multirow[t]{2}{*}{0.13} \\
\hline III/IV & 18 & 32 & \\
\hline \multicolumn{4}{|l|}{$\mathrm{T}$ category } \\
\hline $1,2,3$ & 8 & 34 & \multirow[t]{2}{*}{$0.0025^{*}$} \\
\hline 4 & 12 & 9 & \\
\hline \multicolumn{4}{|c|}{ Lymph node metastasis } \\
\hline- & 2 & 17 & \multirow[t]{2}{*}{$0.012 *$} \\
\hline+ & 17 & 25 & \\
\hline \multicolumn{4}{|c|}{ Lymphatic invasion } \\
\hline- & 2 & 6 & \multirow[t]{2}{*}{0.65} \\
\hline+ & 18 & 37 & \\
\hline \multicolumn{4}{|c|}{ Venous invasion } \\
\hline- & 16 & 33 & \multirow[t]{2}{*}{0.77} \\
\hline+ & 4 & 10 & \\
\hline \multicolumn{4}{|c|}{ Peritoneal metastasis } \\
\hline- & 12 & 38 & \multirow[t]{2}{*}{$0.012 *$} \\
\hline+ & 8 & 5 & \\
\hline \multicolumn{4}{|l|}{ Liver metastasis } \\
\hline- & 10 & 28 & \multirow[t]{2}{*}{0.25} \\
\hline+ & 10 & 15 & \\
\hline
\end{tabular}

*Statistically significant $(p<0.05)$.

therapeutic target and a powerful biomarker for poor prognosis, similar to in gastric cancer. In this study, we first demonstrate that DDR2 functions as an oncogenic factor for PD and is an indicator of poor prognosis. However, the function of DDR2 protein has not yet been clearly elucidated, and further studies are needed to determine the mechanism through which DDR2 promotes cancer progression and PD in CRC.

In conclusion, DDR2 is closely associated with the $\mathrm{Src}$ pathways in CRC, and DDR2 may be a prognostic indicator and a useful therapeutic target, particularly for PD.

\section{Conflicts of Interest}

The Authors declare no conflicts of interest.

\section{Acknowledgements}

This work was supported in part by the following grants and foundations: Japan Society for the Promotion of Science (JSPS) Grant-in-Aid for Science Research (grant nos. 25430111, 25461953, 25861199, and 25861200); Japan Science and Technology Agency (JSTA) A-step (grant no. AS242Z03987P); and the Founding Program for Next Generation World-leading Researchers (grant no. LS094). The Authors are grateful to Ms Tsukumo for her assistance with material preparation.

\section{References}

1 Lemmens VE, Klaver YL, Verwaal VJ, Rutten HJ, Coebergh JW and de Hingh IH: Predictors and survival of synchronous peritoneal carcinomatosis of colorectal origin: a populationbased study. Int J Cancer 128: 2717-2725, 2011.

2 Segelman J, Granath F, Holm T, Machado M, Mahteme H and Martling A: Incidence, prevalence and risk factors for peritoneal carcinomatosis from colorectal cancer. Br J Surg 99: 699-705, 2012.

3 Koppe MJ, Boerman OC, Oyen WJ and Bleichrodt RP: Peritoneal carcinomatosis of colorectal origin: incidence and current treatment strategies. Ann Surg 243: 212-222, 2006.

4 Jayne DG, Fook S, Loi C and Seow-Choen F: Peritoneal carcinomatosis from colorectal cancer. Br J Surg 89: 1545-1550, 2002.

5 Goldberg RM, Sargent DJ, Morton RF, Fuchs CS, Ramanathan RK, Williamson SK, Findlay BP, Pitot HC and Alberts S: Randomized controlled trial of reduced-dose bolus fluorouracil plus leucovorin and irinotecan or infused fluorouracil plus leucovorin and oxaliplatin in patients with previously untreated metastatic colorectal cancer: a North American Intergroup Trial. J Clin Oncol 24: 3347-3353, 2006.

6 Hurwitz H, Fehrenbacher L, Novotny W, Cartwright T, Hainsworth J, Heim W, Berlin J, Baron A, Griffing S, Holmgren E, Ferrara N, Fyfe G, Rogers B, Ross R and Kabbinavar F: Bevacizumab plus irinotecan, fluorouracil, and leucovorin for metastatic colorectal cancer. N Engl J Med 350: 2335-2342, 2004.

7 Franko J, Shi Q, Goldman CD, Pockaj BA, Nelson GD, Goldberg RM, Pitot HC, Grothey A, Alberts SR and Sargent DJ: Treatment of colorectal peritoneal carcinomatosis with systemic chemotherapy: a pooled analysis of north central cancer treatment group phase III trials N9741 and N9841. J Clin Oncol 30: 263-267, 2012.

8 Vaira M, Cioppa T, D'Amico S, de Marco G, D'Alessandro M, Fiorentini $\mathrm{G}$ and De Simone $\mathrm{M}$ : Treatment of peritoneal carcinomatosis from colonic cancer by cytoreduction, peritonectomy and hyperthermic intraperitoneal chemotherapy (HIPEC). Experience of ten years. In Vivo 24: 79-84, 2010.

9 Aoyagi T, Terracina KP, Raza A and Takabe K: Current treatment options for colon cancer peritoneal carcinomatosis. World J Gastroenterol 20: 12493-12500, 2014.

10 Kurashige J, Hasegawa T, Niida A, Sugimachi K, Deng N, Mima K, Uchi R, Sawada G, Takahashi Y, Eguchi H, Inomata M, Kitano S, Fukagawa T, Sasako M, Sasaki H, Sasaki S, Mori M, 
Yanagihara $\mathrm{K}$, Baba $\mathrm{H}$, Miyano $\mathrm{S}$, Tan $\mathrm{P}$ and Mimori $\mathrm{K}$ : Integrated Molecular Profiling of Human Gastric Cancer Identifies DDR2 as a Potential Regulator of Peritoneal Dissemination. Sci Rep 6: 22371, 2016.

11 Bai Y, Kim JY, Watters JM, Fang B, Kinose F, Song L, Koomen JM, Teer JK, Fisher K, Chen YA, Rix U and Haura EB: Adaptive responses to dasatinib-treated lung squamous cell cancer cells harboring DDR2 mutations. Cancer Res 74: 7217-7228, 2014.

12 Terashima M, Togashi Y, Sato K, Mizuuchi H, Sakai K, Suda K, Nakamura Y, Banno E, Hayashi H, De Velasco MA, Fujita Y, Tomida S, Mitsudomi T and Nishio K: Functional Analyses of Mutations in Receptor Tyrosine Kinase Genes in Non-Small Cell Lung Cancer: Double-Edged Sword of DDR2. Clin Cancer Res 22: 3663-3671, 2016

13 Lim SM, Kim HR, Cho EK, Min YJ, Ahn JS, Ahn MJ, Park K, Cho BC, Lee JH, Jeong HC, Kim EK and Kim JH: Targeted sequencing identifies genetic alterations that confer primary resistance to EGFR tyrosine kinase inhibitor (Korean Lung Cancer Consortium). Oncotarget 7: 36311-36320, 2016.

14 Corsa CA, Brenot A, Grither WR, Van Hove S, Loza AJ, Zhang K, Ponik SM, Liu Y, DeNardo DG, Eliceiri KW, Keely PJ and Longmore GD: The Action of Discoidin Domain Receptor 2 in Basal Tumor Cells and Stromal Cancer-Associated Fibroblasts Is Critical for Breast Cancer Metastasis. Cell Rep 15: 25102523, 2016.

15 Gonzalez ME, Martin EE, Anwar T, Arellano-Garcia C, Medhora N, Lama A, Chen YC, Tanager KS, Yoon E, Kidwell KM, Ge C, Franceschi RT and Kleer CG: Mesenchymal Stem Cell-Induced DDR2 Mediates Stromal-Breast Cancer Interactions and Metastasis Growth. Cell Rep 18: 1215-1228, 2017.

16 von Mässenhausen A, Sanders C, Brägelmann J, Konantz M, Queisser A, Vogel W, Kristiansen G, Duensing S, Schröck A, Bootz F, Brossart P, Kirfel J, Lengerke C and Perner S: Targeting DDR2 in head and neck squamous cell carcinoma with dasatinib. Int J Cancer 139: 2359-2369, 2016.

17 Gao Q, Wang ZC, Duan M, Lin YH, Zhou XY, Worthley DL, Wang XY, Niu G, Xia Y, Deng M, Liu LZ, Shi JY, Yang LX, Zhang S, Ding ZB, Zhou J, Liang CM, Cao Y, Xiong L, Xi R, Shi YY and Fan J: Cell Culture System for Analysis of Genetic Heterogeneity Within Hepatocellular Carcinomas and Response to Pharmacologic Agents. Gastroenterology 152: 232-242, 2017.

18 Tsai MC, Li WM, Huang CN, Ke HL, Li CC, Yeh HC, Chan TC, Liang PI, Yeh BW, Wu WJ, Lim SW and Li CF: DDR2 overexpression in urothelial carcinoma indicates an unfavorable prognosis: a large cohort study. Oncotarget 7: 78918-78931, 2016.
19 Fan Y, Xu Z, Fan J, Huang L, Ye M, Shi K, Huang Z, Liu Y, He L, Huang J, Wang $\mathrm{Y}$ and Li Q: Prognostic significance of discoidin domain receptor 2 (DDR2) expression in ovarian cancer. Am J Transl Res 8: 2845-2850, 2016.

20 Ikeda K, Wang LH, Torres R, Zhao H, Olaso E, Eng FJ, Labrador P, Klein R, Lovett D, Yancopoulos GD, Friedman SL and Lin HC: Discoidin domain receptor 2 interacts with Src and Shc following its activation by type I collagen. J Biol Chem 277: 19206-19212, 2002.

21 Russello SV and Shore SK: Src in human carcinogenesis. Front Biosci 8: s1068-1073, 2003.

22 Frame MC: Src in cancer: deregulation and consequences for cell behaviour. Biochim Biophys Acta 1602: 114-130, 2002.

23 Chatzizacharias NA, Kouraklis GP, Giaginis CT and Theocharis SE: Clinical significance of Src expression and activity in human neoplasia. Histol Histopathol 27: 677-692, 2012.

24 Han NM, Curley SA and Gallick GE: Differential activation of pp60(c-src) and pp62(c-yes) in human colorectal carcinoma liver metastases. Clin Cancer Res 2: 1397-1404, 1996.

25 Bolen JB, Veillette A, Schwartz AM, Deseau V and Rosen N: Analysis of pp60c-src in human colon carcinoma and normal human colon mucosal cells. Oncogene Res 1: 149-168, 1987.

26 Bolen JB, Veillette A, Schwartz AM, DeSeau V and Rosen N: Activation of pp60c-src protein kinase activity in human colon carcinoma. Proc Natl Acad Sci USA 84: 2251-2255, 1987.

27 Termuhlen PM, Curley SA, Talamonti MS, Saboorian MH and Gallick GE: Site-specific differences in pp60c-src activity in human colorectal metastases. J Surg Res 54: 293-298, 1993.

28 Talamonti MS, Roh MS, Curley SA and Gallick GE: Increase in activity and level of pp60c-src in progressive stages of human colorectal cancer. J Clin Invest 91: 53-60, 1993.

29 Aligayer H, Boyd DD, Heiss MM, Abdalla EK, Curley SA and Gallick GE: Activation of Src kinase in primary colorectal carcinoma: an indicator of poor clinical prognosis. Cancer 94 : 344-351, 2002.

Received March 4, 2017

Revised April 1, 2017

Accepted April 3, 2017 